\title{
Environmental Justice in
}

Nigeria's Oil Industry:

Recognizing and Embracing

\section{Contemporary Legal \\ Opportunities}

Dr. Rhuks Ako

University of Hull Law School

United Kingdom

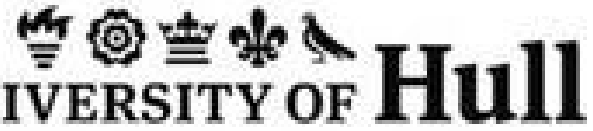




\section{Background}

$\otimes$ Legal framework is main driver of conflicts in Niger Delta; Nigeria's oil region.

* Amnesty initiative introduced to curb restiveness in the region has recorded some success

\& Government has failed to seize the window of opportunity to address fundamental drivers of oil-related conflict; that is the regulatory framework. 


\section{Recent Developments - democratic dividends}

\& Constitutional supremacy

$\otimes$ FHR chapter effective

$\otimes$ Specifically, Land Use Act no longer superior law (s. 315(5)(d) 1999 and s.274(5) 1979

$\otimes$ Restoration of judicial jurisdiction (s.44 - right of court to determine issues of compensation; s.36(1) legal proceedings must be heard by independent/impartial courts/tribunals and $\mathrm{s} .46$ right to $\mathrm{HC}$ to determine where rights has been or likely to be contravened) 


\section{Recent Developments - FREP and Legal Standing}

\&REP 1999 replaces 1979 version.

The fundamental objective of the newer version is to improve access to justice for all classes of litigants especially the poor, the illiterate, the uninformed, the vulnerable, the incarcerated, and the unrepresented (Preamble 3 (d)) by respecting municipal, regional and international bills of rights (Preamble 3 (b) including the African Charter (Preamble 3 (b)(i)) that expressly recognizes the right to a healthy environment. 


\section{Recent Developments - FREP and Legal Standing}

$\$$ Preamble 3(e) of the FREP Rules provides:

\$ The Court shall encourage and welcome public interest litigations in the human rights field and no human rights case may be dismissed or struck out for want of locus standi. In particular, human rights activists, advocates, or groups as well as any non-governmental organizations, may institute human rights application on behalf of any potential applicant. In human rights litigation, the applicant may include any of the following:

* (i) Anyone acting in his own interest;

* (ii) Anyone acting on behalf of another person;

* (iii) Anyone acting as a member of, or in the interest of a group or class of persons;

$\$$ (iv) Anyone acting in the public interest, and

* (v) Association acting in the interest of its members or other individuals or groups. 


\section{Recent Developments - UNIPP}

* Central mission is to promote peaceful integration of indigenous peoples to public participation in the ownership and management of their environmental resources.

8 Develop capacity towards realization of indigenous peoples' rights in line with the UNDRIP and ILO Convention No. 169 in one or more of the following key thematic areas of intervention legislative review and reform; democratic governance and indigenous peoples' institutions; access to justice; access to land and ancestral territories; and natural resources and extractive industries;

UNIPP will promote consultative mechanisms and participatory processes with the State(TOR UNIPP 2010). 


\section{Recent Developments - UNIPP}

\$ The parameters include: the claimant-group's cultures and ways of life must differ considerably from those of the dominant society; their cultures be under threat, in some cases on the verge of extinction; the survival of their particular way of life depends on access and rights to their traditional land and resources; they often live in inaccessible, geographically isolated regions; and they suffer from political and social marginalization and are subject to domination and exploitation within national political and economic structures 


\section{Conclusion}

\$ The ambit of extant environmental legal provisions must utilized rather than decry limitations .

* This paper has highlighted the situation in Nigeria with regards the oil-related environmental issues; what's your experience?

- Academics, NGOs and legal practitioners need to interact more to develop ideas and strategies towards common goal of environmental justice. 